\title{
ARSENIC ADSORPTION INTO THE FIXED BED COLUMN FROM DRINKING GROUNDWATER
}

\author{
VASILE MINZATU ${ }^{1}$, ADINA NEGREA ${ }^{1}$, CORNELIU MIRCEA DAVIDESCU ${ }^{1}$, \\ CORINA SEIMAN DUDA ${ }^{2}$, MIHAELA CIOPEC ${ }^{1}$, NARCIS DUTTEANU ${ }^{1}$, \\ PETRU NEGREA ${ }^{1}$, DANIEL DUDA SEIMAN ${ }^{3} \&$ BOGDAN IOAN PASCU $^{4}$ \\ ${ }^{1}$ University Politehnica Timisoara, Faculty of Industrial Chemistry and Environmental Engineering, \\ Timisoara, Romania \\ ${ }^{2}$ West University of Timisoara, Faculty of Chemistry, Biology and Geography, Timisoara, Romania \\ ${ }^{3}$ Victor Babes University of Medicine and Pharmacy Timisoara, Timisoara, Romania \\ ${ }^{4}$ Research Institute for Renewable Energy of the Politehnica University of Timişoara, Timisoara, Romania
}

\begin{abstract}
One of the main goals of the World Health Organization (WHO) and its Member States is that "all people, regardless of their stage of development and their social-economic condition, have the right to have access to adequate drinking water". The problem of remediation of waters contaminated with toxic substances, using natural resources, is a special concern at a high level. Researchers' efforts have sought to find effective and cheap ways to reduce the impact on the environment. As(III) gets into the environment from a variety of natural and anthropogenic sources. As As(III) is commonly found in rocks, soil or sediments, these sources are particularly important determinants of the As(III) zonal level in groundwater and surface water. As(III) contamination is currently one of the major problems with serious consequences on the biosphere. The main objective of this paper is the establishment of a method for the removal of As(III) from real waters by adsorption in a fixed bed column, using ecological materials, friendly to the environment. For this reason, the content of As(III) in groundwaters in the Romania-Hungary border area was determined, knowing the fact that the Pannonian Basin was given special attention, being an area heavily affected by As(III) contamination of natural water sources. The paper studies the adsorption of As(III) from a natural water taken from the monitored area. At the same time, it has followed the behaviour of microorganisms naturally existing in the soil of Timisoara city and in the Bega river in the presence of different amounts of As(III) in order to establish the relative toxicity of As(III) in them.
\end{abstract}

Keywords: As(III), groundwater, adsorption, fixed bed column, toxicity.

\section{INTRODUCTION}

One of the main goals of the World Health Organization (WHO) is: "all people, regardless of their developmental stage and their social economic condition, have right to access adequate drinking water" [1].

Last decade's research proved that the groundwater sources used as drinking water sources are contaminated with As(III), which represent a real problem and become a challenge for scientists.

As(III) is a metalloid which can be found in nature as trivalent or penta-valent ions. Generally, the trivalent form was founded in ground waters and the penta-valent one into the surface waters [2], [3]. As(III) toxicity is a complex phenomenon and in general is classified as acute and sub-acute, his toxicity being dependent on the form in which it is found into the contaminated water. Inorganic form of As(III), typically found in the drinking water resource is more toxic then As(III) organic compounds found in the seawater. From all As(III) compounds those with the highest toxicity are the compounds containing trivalent As(III) ions [4], [5].

Acute poisoning with As(III) occurs mostly by ingestion of contaminated food or water and requires immediate medical attention. 
After consumption of As(III) contaminated water, the As(III) ions are adsorbed and transported into the body through the bloodstream. The human body is able to eliminate As(III) mainly through urine, but small amounts are eliminated through skin pores, hair, nails and sweat.

Short term exposure (days, weeks) at a higher As(III) concentration present in drinking water can lead to abdominal pain, vomiting, diarrheal disease, muscular cramp, skin weakness and redness, rash, numbness, tingling or burning sensation in the hands and feet, skin thickening at level of palms or feet soles, and can culminate with the loss of movement and sensorial responses [6], [7].

Long-term exposure to As(III) contaminated water can mainly cause dysfunctions of the kidneys and after that affects the internal organs such as: lungs, liver, gall bladder, and can also cause skin lesions [6]-[8].

Regardless of the sources that generate As(III) (natural or anthropic), it reaches the underground or surface waters where it suffers a series of physical, chemical and biological processes, such as: oxidation - reduction reactions, ligands exchanges and/or biotransformation.

Physical-chemical processes that can affect the evolution and the transport of As(III) ions into the ground and surface waters are similar and are influenced by $\mathrm{pH}$, oxidation-reduction potential, temperature, salinity, concentration of iron and manganese ions, content of other ions found in water, and by the composition of Earth's crust [10], [11].

Most knowledge regarding natural microorganism activity was deduced from their study under laboratory conditions. Subsequently, studies were carried out in microorganism natural environment using progressively improved analytical methods [5], [7].

In order to understand the activity of natural microorganisms we need to study the activity of a single class of microorganisms in order to see how they are affecting the environment and in order to see how the environment is affecting the microorganism population. Simultaneously it is important to study the microorganism populations, and complex microorganism systems [7].

Presence and development of microorganism into the aquatic environment are influenced by light, temperature, hydrostatic pressure, turbidity, dissolved gases, flow rate, depth, mineral and organic content [6]. Microorganisms take from surrounding environment nutrients and energy used in their fundamental activities; such nutrients are essential elements for cell life and are called biogenic elements [9].

As(III) removal from water represents an important concern and is realised using a series of techniques, such as: precipitation-filtration [12], coagulation-precipitation [13], separation by combined processes such as: photo-catalysis combined with complexation and filtration, electrocoagulation, electro-dialysis, nano-filtration, inverse osmosis, ion exchange technology, adsorption on zeolites and activated carbons [14], [15]. Cheap adsorbent such as waste and agriculture secondary products [16], oxides (manganese dioxide, activated alumina, titanium dioxide, iron oxide), hydroxides (lanthanum hydroxides), oxo-hydroxides, macroporous polymers, ion exchange resins, chelating resins, biopolymers (cellulose, human hair) are used today for As(III) removal [17]-[22].

Adsorbent material used in the present study is a composite material based on carbon and iron oxide, synthesized from cheap precursors, starch and ferric chloride. The main purpose of this study was to establish a mechanism for As(III) removal from water by adsorption in a fixed bed column, using eco-friendly materials. For this purpose, the As(III) content was determined in groundwaters from Romanian-Hungarian border, part of the Pannonian Basin. Waters from this basin receive a special attention because they are contaminated with As(III). Also, was studied the influence of different other ions dissolved into the water onto the 
As(III) removal process. Subsequently the behaviour of some natural microorganisms found in Timisoara soil and Bega river was studied in the presence of different amounts of As(III) in order to determine its toxicity.

\section{MATERIALS AND METHODS}

In order to establish the adsorption mechanism of As(III) ions from natural ground water in dynamic regime through fixed bed column, using as adsorbent a composite material containing carbon and iron oxide, water samples were taken from public fountains located along Romanian - Hungarian border. For all samples some parameters were determined: As(III) concentration, $\mathrm{pH}$, nitrite, nitrate, ammonium, phosphates, and bicarbonates quantities using standardized analytic methods, specific for each parameter.

For material synthesis as environmental friendly precursor starch was used for the carbon support (starch soluble extra pure, $\mathrm{pH} 6.0-7.5,20 \mathrm{~g} / \mathrm{L}^{-1} \mathrm{H}_{2} \mathrm{O}, 298 \mathrm{~K}$ ), and as precursor for iron oxide was used ferric chloride bought from Merck.

$20 \mathrm{~g}$ of soluble starch was dissolved in $25 \mathrm{~mL}$ of DI water and heated at $331 \mathrm{~K}$, over which was added under continuous stirring a $33 \%$ ferric chloride. These amounts of precursors were chosen in order to get a final ratio $\mathrm{Fe}: \mathrm{C}$ equal to $1: 10$. The obtained paste was dried at $325 \mathrm{~K}$ for minimum 20 hours, grinded and subjected to thermal treatment at minimum $850 \mathrm{~K}$ in inert atmosphere.

The obtained material was characterized using Quanta FEG 250 X-ray dispersion coupled electron microscope (SEM-EDX). The adsorption of As(III) was performed in dynamic mode using a glass column with inner diameter of $2.5 \mathrm{~cm}$ and length of $30 \mathrm{~cm}$, loaded with $10 \mathrm{~g}$. of prepared adsorbent material. In order to prevent clogging of the column, the composite material was mixed with quartz sand with grain between $0.6-1.85 \mathrm{~mm}$ using different ratios of sand: adsorbent material: 9:1; 1:1 and 3:7 Real water containing $191 \mu \mathrm{g} / \mathrm{L}^{-1} \mathrm{As}$ (III) with $\mathrm{pH} 7.5$ was introduced into the column using a HEIDOLF peristaltic pump with a flow-rate of $10 \mathrm{~mL} \mathrm{~min}{ }^{-1}$.

As(III) concentrations were determined by using inductively coupled plasma mass spectrometry ICP-MS BRUKER AuroraM90.

As(III) toxicity was determined by observing the behaviour of microorganisms naturally existing in Timisoara soil and in the Bega river water in presence of different As(III) concentrations (10, 50, 100, 200, 500, 800, $1000 \mu \mathrm{g} \mathrm{As}(\mathrm{III}) / \mathrm{L}$ and 10, 100, $500 \mathrm{mg} \mathrm{As(III)/L).}$ Microorganisms culture was obtained by using two different methods: by flooding of the environment with the enriched culture and by embedding the microorganism into the environment, for both water and soil. The filter papers soaked into the As(III) solution with different concentrations were placed over the microorganism culture. Filter papers were placed in ascending orders of As(III) concentrations, clockwise. As(III) was added into the culture environment in form of As(III) ions and the microorganism growth was realized at $310 \mathrm{~K}$. Culture plates where then analysed in order to quantify the number of microorganisms growth in each environment, depending on the As(III) concentration. Similar environment but in liquid form was used for microbial biomass production in order to test it on the As(III) contaminated soils.

\section{RESULTS AND DISCUSIONS}

\subsection{Determination of $\mathrm{As}(\mathrm{III})$ content in ground waters in Romania-Hungary border area}

The content of As(III) in ground waters (public water wells and fountains) in the RomanianHungarian cross-border area is shown in Table 1. 
Table 1: Cross-border groundwater monitoring.

\begin{tabular}{|c|c|c|c|}
\hline $\begin{array}{l}\text { Index } \\
\text { number }\end{array}$ & Water samples & $\begin{array}{l}\text { As }(\mathrm{III}) \text { content, } \\
\left(\mu \mathrm{g} / \mathrm{L}^{-1}\right)\end{array}$ & $\begin{array}{c}\text { Maximum } \\
\text { allowed } \\
\text { concentration } \\
\text { (MTC) }\end{array}$ \\
\hline 1 & Pecica, Arad county, drilling 1 & 191 & \multirow{14}{*}{$\begin{array}{c}10 \mu \mathrm{g} / \mathrm{L}^{-1} \\
\mathrm{As}(\mathrm{III})\end{array}$} \\
\hline 2 & Pecica, Arad county, drilling 2 & 0.31 & \\
\hline 3 & Pecica, Arad county, drilling 3 & 34.9 & \\
\hline 4 & Pecica, Arad county, drilling 4 & 8.50 & \\
\hline 5 & Timişoara, drilling 1 & 4.73 & \\
\hline 6 & Timişoara, drilling 2 & 8.38 & \\
\hline 7 & Timişoara, drilling 3 & 3.44 & \\
\hline 8 & Arad, drilling & 8.45 & \\
\hline 9 & Algyő, Hungary, drilling & 7.20 & \\
\hline 10 & Újszentiván, Hungary, family drilling & 17.5 & \\
\hline 11 & Ásotthalom, Hungary, family fountain & 90.8 & \\
\hline 12 & Szatymaz. Hungary, family fountain & 14.3 & \\
\hline 13 & Szeged, Hungarya, drilling & 57.7 & \\
\hline 14 & Sandorfalva, Hungary, drilling & 7.26 & \\
\hline
\end{tabular}

Obtained experimental data depicted in Table 1 confirms that the fountains located in the Hungarian part of the border contain higher amounts of As(III). In almost all of the cases this concentration exceeds the maximum allowed concentration. However, it is observed that there is no exceeding of maximum allowed concentration in case of Timisoara wells, but one exceeding was observed in Pecica, Arad county. Due to this fact, the further step into the experimental study is the elimination of As(III) for all the samples by adsorption on carbon based composite materials, using a dynamic regime.

\subsection{Characterization of adsorbent material}

\subsubsection{Material characterization by electronic scanning microscopy SEM}

Images obtained from SEM are depicted in Fig. 1. Analysing the data presented in Fig. 1 we can observe the presence of iron oxide particles onto the surface of carbon material, and a relative homogenous distribution of these particles over de material surface Fig. 1(a). All iron oxide particles present the crystallite size between $630 \mathrm{~nm}$ and $1060 \mathrm{~nm}$ Fig. 1(b).

\subsubsection{Material characterization using X-ray dispersion (EDX)}

To study the interaction between carbon and iron particles, the synthesized material was subjected to elemental EDX analysis (X-ray dispersion spectral analysis) presented in Fig. 2. From the obtained EDX spectrum the presence of peaks characteristic of iron and oxygen atoms is observed, which confirms the modification of the graphite surface. 


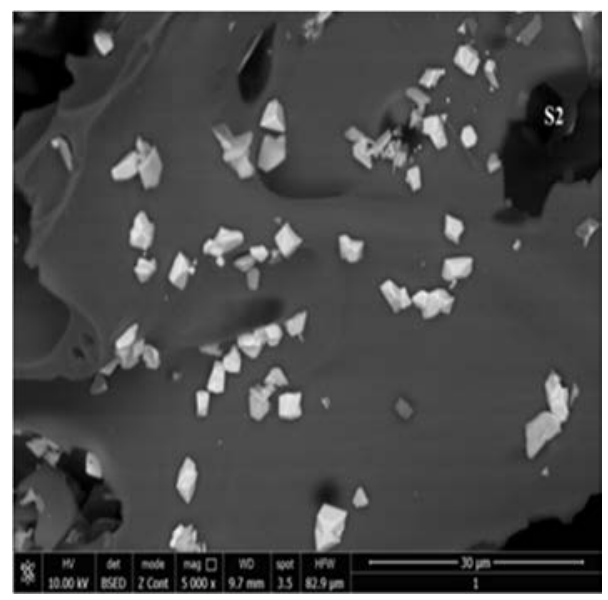

(a)

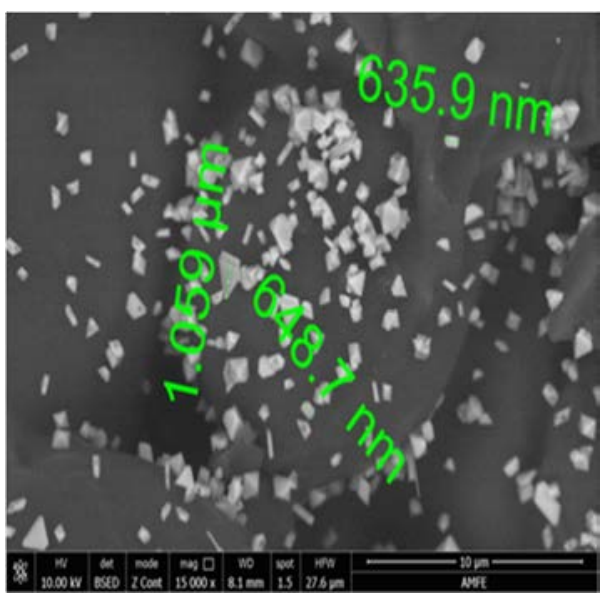

(b)

Figure 1: SEM images.

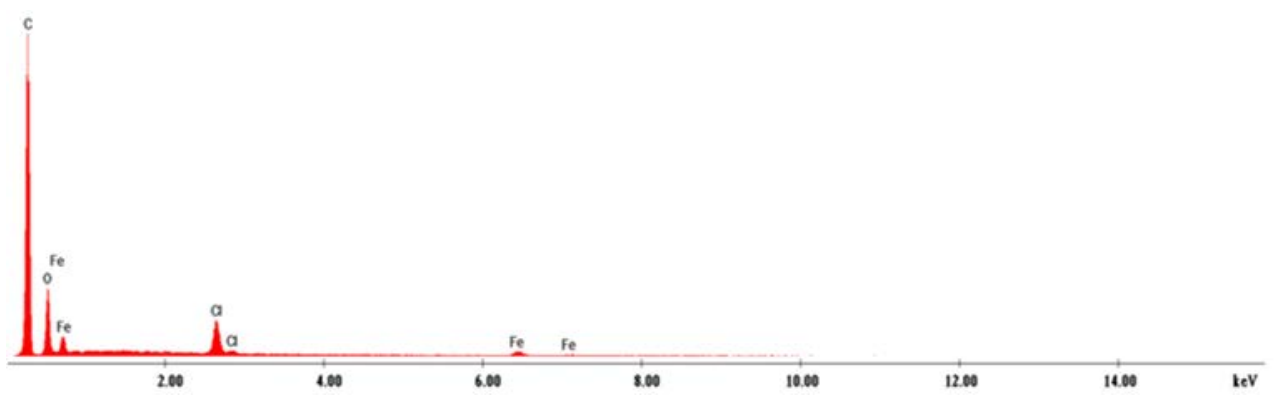

Figure 2: EDX elemental analysis.

3.3 Elimination of As(III) from deep water by dynamic adsorption.

Influence of foreign ions.

\subsubsection{As(III) adsorption on the column}

During experiments was observed the clogging of the adsorbent columns, which can be explained if we are taking into account the small dimensions of the synthesized composite materials. In order to avoid the clogging of the adsorbent column the adsorbent material was mixed in different ratio with quarts sand.

As(III) ions adsorption on the column was studied following the dependence of residual concentration and the adsorption capacity of used adsorbent material, as function of the mixing ration between adsorbent material and quartz sand, dependencies depicted in Figs 3 and 4.

Analyzing experimental data depicted in Fig. 3 it can be observed that by increasing the quantity of the composite adsorbent material into the mixture, the volume of water contaminated with As which is passed through column is increased until the breakdown of the column. 


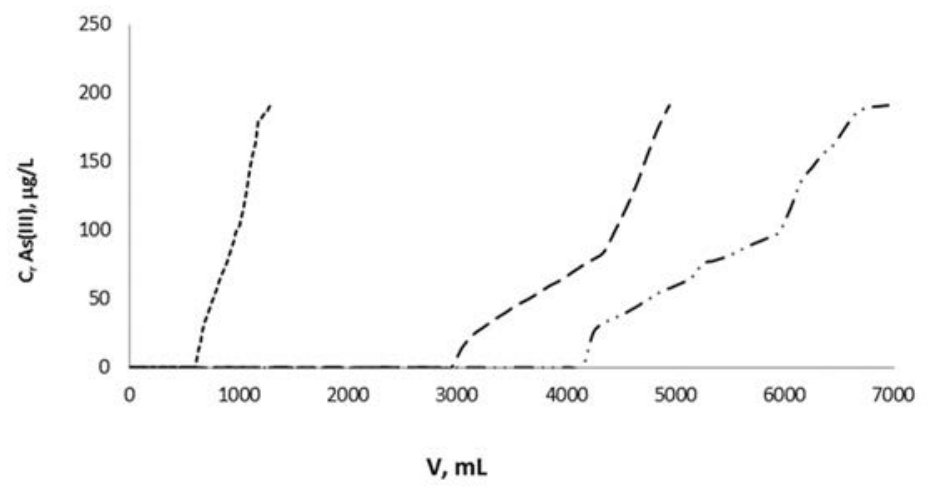

Figure 3: Dependence of residual concentrations on the volume of solution passed through the column, for different $(\mathrm{w} / \mathrm{w})$ composite material:sand ratios.

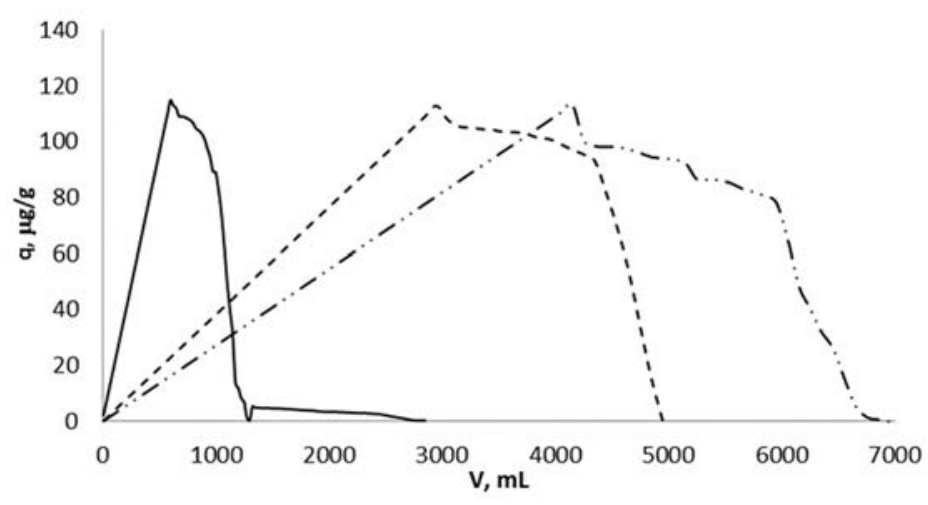

Figure 4: Dependence of the adsorption capacity of As(III) on the adsorbent material for different composite materials and ratios.

It can also be observed that for the sand: adsorbent material ratio of 9:1, the water volume passed through the column until its breakdown was $600 \mathrm{~mL}$, similar for a sand:adsorbent material ratio of 1:1 the volume of solution was $2950 \mathrm{~mL}$ and for the 3:7 ratio, the volume of solution was $4150 \mathrm{~mL}$.

Based on data depicted in Fig. 4 it can be observed that the maximum adsorption capacity of the produced adsorbent material is $110 \mu \mathrm{g}$ per gram of composite material, corresponding to the maximum efficiency. At this value the residual concentration of As ions is minimum, and further usage of the adsorbent material leads to decrease of the adsorption capacity until the residual concentration reaches the initial concentration of the As ions, representing the moment when the column is breakdown.

3.3.2 Influence of other ions present in water on the adsorption process of As(III) Experimental data presenting the influence of other ions present in water on the process of As(III) elimination using carbon based composite material are presented in Table 2. 
Table 2: Influence of ions present in water on the adsorption process of As(III).

\begin{tabular}{|c|c|c|c|c|c|c|c|}
\hline Parameter & $\mathrm{pH}$ & $\begin{array}{c}\mathrm{As}(\mathrm{III}), \\
\mu \mathrm{g} / \mathrm{L}\end{array}$ & $\begin{array}{c}\mathrm{NO}_{2}^{-}, \\
\mathrm{mg} / \mathrm{L}\end{array}$ & $\begin{array}{c}\mathrm{NO}_{\bar{z}}^{-}, \\
\mathrm{mg} / \mathrm{L}\end{array}$ & $\begin{array}{c}\mathrm{NH}_{4}^{+}, \\
\mathrm{mg} / \mathrm{L}\end{array}$ & $\begin{array}{c}\mathrm{PO}_{4}^{3-}, \\
\mathrm{mg} / \mathrm{L}\end{array}$ & $\begin{array}{c}\mathrm{HCO}_{3}^{-}, \\
\mathrm{mg} / \mathrm{L}\end{array}$ \\
\hline $\mathrm{H}_{2} \mathrm{O}$ initial & 7.5 & 191 & 0.3 & 35.6 & 0.9 & 19.5 & 435 \\
\hline $\mathrm{H}_{2} \mathrm{O}$ treated & 6.5 & $<0.01$ & 0.1 & 32.4 & 0.4 & 4.6 & 278 \\
\hline
\end{tabular}

From the experimental data depicted in Table 2 it can be observed that in addition to the adsorption of the As(III), the used adsorbent material exhibits adsorption capabilities for other ions present in the water. It was also noted that the adsorbent material presents affinity for the phosphate anions reducing them from $19.5 \mathrm{mg} / \mathrm{L}^{-1}$ to $4.5 \mathrm{mg} / \mathrm{L}^{-1}$. It is known from literature that phosphorous and As(III) have the same geochemical behaviours, and both of them are competing for adsorption onto the surface of hydrated iron oxides, which was also confirmed from obtained experimental data. Also, it can be observed that the produced adsorbent material exhibits adsorbent capacity for bicarbonate ions. Based on experimental data it can be concluded that the produced adsorbent material presents adsorbent capacities for As(III) ions and for the competing ions present into the real waters.

\subsubsection{As(III) toxicity studies}

Behaviours of microorganism obtained from Bega river into the presence of the As(III) with the following concentrations: 10, 50, 100, 200, 500, 800, and $1000 \mu \mathrm{g} \mathrm{As}(\mathrm{III}) \mathrm{L}^{-1}$ and 10, $500,1000 \mu \mathrm{g} \mathrm{As}(\mathrm{V}) \mathrm{L}^{-1}$ are shown in Fig. 5(a). From Fig. 5 it can be observed that the bacteria obtained from Bega river grow well into the presence of As(III) solutions. Based on that we can conclude that the microbial flora found into the Bega river shows a natural resistance to the used As(III) concentrations.

Behaviour of bacteria obtained from Timisoara soil into the presence of As(III) with similar concentrations is depicted in Fig 5(b). From Fig. 5(b) it can be observed that the bacteria presents a high growth rate in the presence of As(III) solutions, so it can be concluded that the bacterial flora found into the Timisoara soil exhibits a natural resistance at used As(III) concentrations.

Because the concentration of As(III) initially used was not toxic for the water and soil bacterial population, in order to determine the minimum toxic concentration of As(III) in the solution, the As(III) concentration was increased to $10 \mathrm{~g} / \mathrm{L}^{-1} \mathrm{As}(\mathrm{III})$ and, subsequently to $25 \mathrm{~g} / \mathrm{L}^{-1} \mathrm{As}(\mathrm{III})$. The obtained results are presented in Fig. 6. By analysing Fig. 6 it can be observed that, at the initial concentration of As(III) of $10 \mathrm{~g} / \mathrm{L}^{-1}$, the bacterial growth is not inhibited, all bacteria showing a normal behaviour.

By analysing the data obtained when the initial concentration of As(III) was $25 \mathrm{~g} / \mathrm{L}^{-1}$, the appearance of a well visible inhibition zone can be observed, thus this concentration is the lowest toxic concentration for the bacteria presented in the water and soil.

\section{CONCLUSIONS}

The purpose of this study was to establish a mechanism for the removal of As(III) from real water by using the adsorption into a fixed bed column, filled with eco-friendly adsorbent materials. For this purpose, the content of As(III) was determined in the groundwater from the Romanian-Hungarian border. Also, the influence of the other dissolved ions onto the As(III) adsorption was studied, and in same time the behaviour of microorganism found in the Timisoara soil and Bega river was studied in the presence of different As(III) concentrations in order to determine its toxicity. 


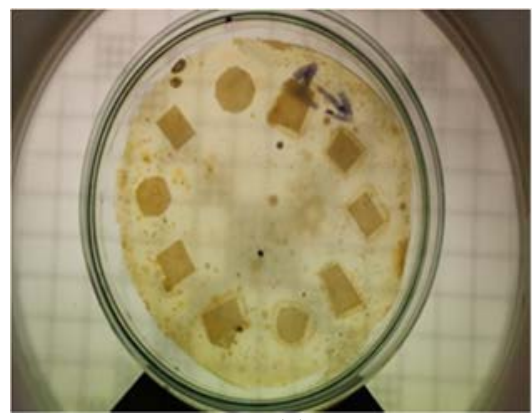

(a)

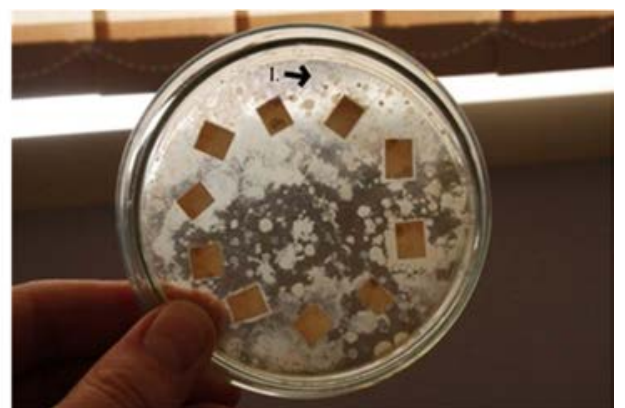

(b)

Figure 5: The behaviour of microorganisms in water and soil in the presence of As(III) after $48 \mathrm{~h}$ of incubation.

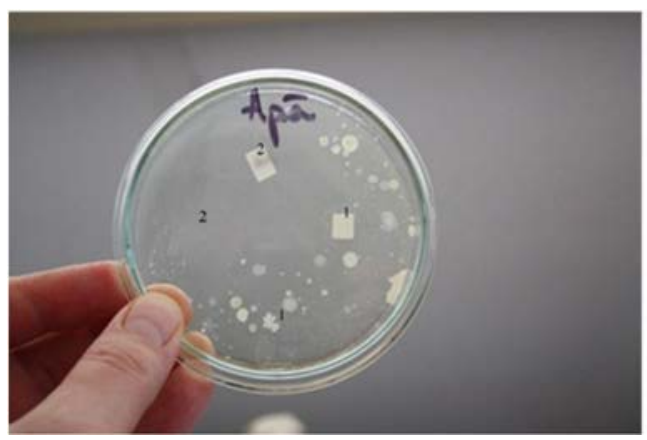

(a)

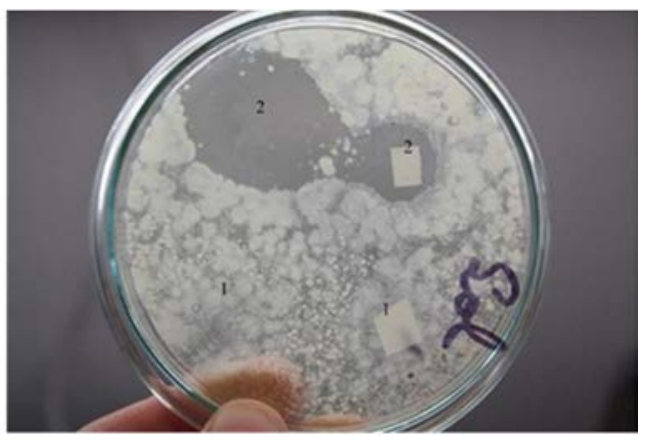

(b)

Figure 6: The behaviour of microorganisms in the presence of 10 and $25 \mathrm{~g} \mathrm{As}(\mathrm{III}) / \mathrm{L}$ after 46 hours of incubation.

From water analysis a higher variation of As(III) concentration can be observed in the ground water, from the maximum allowed concentration $\left(10 \mu \mathrm{g}\right.$ As(III) $\left.\mathrm{L}^{-1}\right)$ up to a maximum concentration of $191 \mu \mathrm{g} \mathrm{As}(\mathrm{III}) \mathrm{L}^{-1}$. Exceeding the maximum allowed concentration was observed for low depth wells ( 5 to $20 \mathrm{~m}$ ) and for very deep wells ( $>230 \mathrm{~m}$ ).

In order to establish the adsorption performance of the synthesized adsorbent material in dynamic regime the following were studied: the variation of As(III) residual concentration, the adsorption time, the capacity and the efficiency of the adsorption process as a function of volume of water passed through column filled with adsorbent material, that depends on the quartz sand to adsorbent material ratio. From experimental data it can be observed that with an increase in the adsorbent material to quartz sand ratio, the volume of water passed through the column increases until the breakdown of the column at a ratio of $3: 7$; over this ratio the clogging of the adsorbent column is observed.

Thus, when a quantity of 10 grams of mixture was introduced into the column at a sand to adsorbent material ratio of 1:9, the water volume which passed through the column was $600 \mathrm{~mL}$ in one hour until the column was broke down. For the 1:1 ratio the volume of water was $2950 \mathrm{~mL}$ which passed through the column in 5 hours, and for the 7:3 ratio the volume of water which passed through column was $4150 \mathrm{~mL}$ in 7 hours. 
Based on experimental data it can be concluded that the optimal sand to adsorbent material ratio is 7:3. The maximum adsorption capacity is $112 \mu \mathrm{g}$ As(III) per gram of adsorbent material. Also, it was found that the produced adsorbent material exhibits adsorbent properties for the other ions dissolved into the groundwater. As(III) toxicity studies were carried out using microorganism obtained from Timisoara soil and from Bega river. From the obtained experimental data, a natural resistance of the microorganism to the As(III) concentrations was observed until $10 \mathrm{~g} \mathrm{As}$ (III) $\mathrm{L}^{-1}$. When the As(III) concentration reach $25 \mathrm{~g} / \mathrm{L}^{-1}$, solution becomes toxic for microorganisms obtained from Timisoara soil and Bega river.

\section{ACKNOWLEDGEMENTS}

This work was partially supported by research grants PCD-TC-2017. Authors gratefully acknowledge use of the services and facilities of the Research Institute for Renewable Energy of the Politehnica University of Timişoara, founded by National Authority for Scientific Research and Innovation, through Priority Axis 2: Competitivity through research, technological development and innovation, Domain 2.2: Investments in the researchdevelopment-innovation infrastructures; Operation 2.2.1: Development of existing RD infrastructures and creation of new RD infrastructures.

\section{REFERENCES}

[1] World Health Organization, Preventing Disease through Healthy Environments Exposure to Lead: A Major Public Health Concern, WHO: Geneva, 2010.

[2] Zhang, L., Qin, X., Tang, J., Liu, W. \& Yang, H., Review of arsenic geochemical characteristics and its significance on As(III) pollution studies in karst groundwater, Southwest China. Applied Geochemistry, 77, pp. 1-9, 2016.

[3] Barringer, J.L. \& Reilly, P.A., Arsenic in Groundwater: A Summary of Sources and the Biogeochemical and Hydrogeological Factors Affecting Arsenic Occurrence and Mobility, INTECH Open Access Publisher, pp. 83-116, 2013.

[4] Alexander, M., Biodegradation and Bioremediation, Academic Press: San Diego, New York, Boston, London, Tokyo and Toronto, 1994.

[5] Huang, Q., Xi, G., Alamdar, A., Zhang, J. \& Shen, H., Comparative proteomic analysis reveals heart toxicity induced by chronic arsenic exposure in rats. Environmental Pollution, 229, pp. 210-218, 2017.

[6] Kesici, G.G., Arsenic ototoxicity. Journal of Otology, 11, pp. 13-17, 2016.

[7] Beard, S.J., Hashim, R., Hernandez, J., Hughes, M. \& Poole, R.K., Zinc (II) tolerance in Escherichia coli K-12: Evidence that the zntA gene (o732) encodes a cation transport ATPase. Molecular Microbiology, 25(5), pp. 883-891, 1997.

[8] Halina, B.R., Kalavati, C., Bukola, G.O. \& Odland, J.O., Evaluation of in utero exposure to arsenic in South Africa. Science of the Total Environment, 575, pp. 338346, 2017.

[9] Alexander, M., Biodegradation and Bioremediation, Academic Press: San Diego, New York, Boston, London, Tokyo and Toronto, 1994.

[10] Arpan, S. \& Biswajit, P., The global menace of arsenic and its conventional remediation - A critical review. Chemosphere, 158, pp. 37-49, 2016.

[11] Nickson, R.T., McArthur, J.M., Ravenscroft, P., Burgess, W.G. \& Ahmed, K.M., Mechanism of arsenic release to groundwater, Bangladesh and West Bengal. Applied Geochemistry, 15(4), pp. 403-413, 2000. 
[12] Dinesh, M., \& Pittman, C.U. Jr., Arsenic removal from water/wastewater using adsorbents - a critical review. Journal of Hazardous Materials, 142(1)-(2), pp. 1-53, 2007.

[13] Song, S., Lopez-Valdivieso, A., Hernandez-Campos, D.J., Peng, C., MonroyFernandez, M.G. \& Razo-Soto, L., As(III) removal from high-arsenic water by enhanced coagulation with ferric ions and coarse calcite. Water Research, 40, pp. 364 372, 2006.

[14] Bora, A.J., Gogoi, S., Gautam, B. \& Robin, K., Dutta, utilization of co-existing iron in arsenic removal from groundwater by oxidation-coagulation at optimizated $\mathrm{pH}$. Journal of Environmental Chemical Engineering, 4, pp. 2683-2691, 2016.

[15] Rajesh, M. et al., Removal of arsenic (III) from water by magnetic binary oxide particles (MBOP): Experimental studies on fixed bed column. Journal of Hazardous Materials, Part B, pp. 469-478, 2017.

[16] Samfira, I. et al., Remediation of rare earth element pollutants by sorption process using organic natural sorbents. International Journal of Environmental Research and Public Health, 12, pp. 11278-11287, ISSN-1660-4601, 2015.

[17] Dandan, Z., Yang, Y., Chenghong, W. \& Chen, J.P., Zirconium/PVA modified flatsheet PVDF membrane as a cost-effective adsorptive and filtration material: A case study on decontamination of organic arsenic in aqueous solutions. Journal of Colloid and Interface Science, 477, pp. 191-200, 2016.

[18] Salazar, H., Poly(vinylidene fluoride-hexafluoropropylene)/bayerite composite membranes for efficient arsenic removal from water. Materials Chemistry and Physics, 183, pp. 430-434, 2016.

[19] Chang-Gu, L., Arsenic(V) removal using an amine-doped acrylic ion exchange fiber: Kinetic, equilibrium, and regeneration studies. Journal of Hazardous Materials, 325, pp. 223-229, 2017.

[20] Iberhan, L. \& Wisniewski, M., Removal of arsenic(III) and $\operatorname{arsenic}(\mathrm{V})$ from sulfuric acid solution by liquid-liquid extraction. Journal of Chemical Technology \& Biotechnology, 78, pp. 659-665, 2003.

[21] Borah, D., Satokawa, S., Kato, S. \& Kojima, T., Surface-modified carbon black for As(V) removal. Journal of Colloid and Interface Science, 319(1), p. 53, 2008.

[22] Mohan, D. \& Pittman, C.U. Jr., Arsenic removal from water/wastewater using adsorbents - a critical review. Journal of Hazardous Materials, 142(1)-(2), pp. 1-53, 2007. 